\title{
How to Improve the Efficiency of College English Classroom Teaching
}

\author{
Linlin Tong \\ Tianshi College China Tianjin 301700
}

Keywords: College English; Current situation; Classroom efficiency; Measures

\begin{abstract}
At present, the efficiency of English classroom teaching in Colleges and universities is low, so it is difficult to meet the needs of social development and progress. How to effectively improve the efficiency of College English classroom has become an important research topic in college education. In this paper, the author analyzes the current situation and existing problems of College English teaching combined with some problems encountered in practice teaching and related information, and puts forward measures to improve English teaching efficiency from multiple perspectives.

With the deepening of the process of economic globalization, English plays a more important role in people's life. Especially for college students, in addition to professional knowledge, English ability is also indispensable. From the perspective of practical English teaching, our college students' English level has not yet achieved the expected goal, because the efficiency of College English classroom teaching is not high. Based on this background, the author has studied how to improve the efficiency of English class and cultivate more excellent English talents for the development of the society.
\end{abstract}

\section{Part One Current Situation and Existing Problems of College English Classroom Teaching}

In recent years, colleges and universities have done a lot of research and reform in order to improve the efficiency of English classroom teaching. Although the efficiency of English teaching has been improved, there are still some problems, which make the teaching efficiency fail to achieve the desired goals. The author summarizes the following problems from the practice teaching:

The Inculcate Teaching Method Still Exists, Which Causes the Students' Interest in English Learning is not High

At present, the teaching thinking and methods of some English teachers in Colleges and universities still follow the traditional teaching mode, which is especially reflected in the old teachers. Because they are deeply influenced by the traditional teaching mode, it is difficult for them to accept new teaching ideas in short time. Even some teachers will put up a shelf of "academic conserving". They think they have rich experience in teaching, and they can take up textbooks, or write lots of blackboard writing. This traditional teaching methods can not meet the needs of modern education, and traditional teaching methods are easy to let the students have tired of emotions. Therefore, the current situation in College English classroom is teachers' lectures on the rostrum. Students are sleeping, playing cell phones and reading magazines. Some students have been tired of the way the teacher has been lecturing, not to speak of self - study.

\section{Lack of High Quality and High Level English Teachers' Team}

In English classroom teaching activities, teachers play a very important role, and the efficiency of teaching depends on the quality of teachers to a great extent. At present, the main problem the school is facing is the lack of high quality and high level English teachers' team, and it is urgent to improve their professional and teaching abilities. In addition, in recent years, the enrollment scale of our school has been growing, and the resources of English teachers are becoming more and more tense, which has added a heavy burden to the teaching. Teachers have a large number of hours, and they are in a state of exhaustion every day. It will directly affect the efficiency of classroom teaching for a long time.

The Form of English Classroom Activities is Dull and Monotonous, and the Students Lack the Interest of Participation

Classroom activities have a direct impact on the overall efficiency of the classroom, so effective 
classroom design is critical. At present, in some college English classroom activities, classroom activities are basically teachers' simple questions, or students have doubts to ask teachers for advice, while oral communication activities are also mainly based on role playing. The classroom activities form is single and lack of innovation, it is difficult to mobilize the enthusiasm of the students and the sense of participation, also let students feel tired, and classroom efficiency is not high, and even some students in classroom activities have tired of psychology, long past students lose interest in learning English.

\section{Blindly Chasing the Teaching Progress and Influencing the Quality of Teaching}

In Colleges and universities, there will be a problem of catching up. For example, for the English class test, some teachers in order to improve the English grade test pass rate, they have to occupy the class time to help the students to prepare for the exam. Because of the classroom time, teachers are worried that they can not finish the teaching task, and can only take the way to speed up the speed of teaching. Usually, in order to catch up with progress, teachers will always lecture, and students' exercise time is reduced. When knowledge is not consolidated, teachers will start talking again. For a long time, the students have not learned the knowledge, and begin to learn new knowledge, it is not worth the loss, thus affecting the efficiency of the classroom.

\section{Part Two Strategies and Reflections on Improving the Efficiency of College English Class}

College English classroom is not only the position of teachers' teaching, but also the place for students to learn. Therefore, there are two important factors affecting classroom efficiency, that is, teachers and students must integrate teachers' teaching with students' learning effectively, so as to achieve the desired teaching effect. The following is the author's suggestion to improve the efficiency of English class.

\section{Students' Subjective Initiative should be Reflected in English Classroom Teaching}

The subjective initiative of the students is one of the factors that affect the efficiency of the English class. In modern educational philosophy, the status of teachers has changed. This requires teachers to correctly understand their functions and status, mobilize their enthusiasm and carry out teaching activities. Only in this way can we highlight the importance and subjective initiative of the students in the classroom, instead of looking at the other side, allowing the students to develop freely or to pay much attention to the students with good grades. The author believes that as an English teacher, the following points should be made to stimulate the subjective initiative of the students.

Giving Full Play to the Teacher's Leading Role in the Classroom and Giving Prominence to the Students' Main Position. In College English teaching, teachers must clarify their role, play a leading role in class, the only way to achieve good teaching effect, to stimulate the initiative of students, encourage students' autonomous learning, gradually improve the ability of autonomous learning. Compared with primary and secondary school students, college students are already adults, have their own thinking ability, and have strong hands-on ability, and have the consciousness of independence. This requires that teachers do not like to treat pupils, or college students will think that teachers do not respect them, and even deprive them of their freedom. It can be seen that as a college English teacher, we should face up to ourselves, make classroom leaders, promoters and guides adhere to classroom teaching, focus on students' interests and needs, and gradually guide students to learn and improve their English ability.

Learn to Deal with the Relationship Between Teachers and Students. The relationship between teachers and students is also a factor affecting the efficiency of the classroom, and the relationship between teachers and students should be friendly and harmonious. It is good to say, "believe the teacher, believe the way". In education, colleges and universities has been advocating the teacher's dignity, but from the practice of teaching, if the teacher has been in a serious state, it will become alienated from the relationship between teachers and students, and even students of teachers only fear, not willing to participate in classroom activities, it is difficult to arouse the students' enthusiasm for English. Therefore, teachers should start from establishing good teacher-student relationship, treat students equally, enable students to feel the kindness of teachers, 
and create a relaxed and pleasant classroom atmosphere for students. This can effectively improve the efficiency of the classroom.

Create a Good Atmosphere for English Learning. The survey shows that students can devote themselves to learning in a relaxed atmosphere, and their learning efficiency is very high. Moreover, such a learning atmosphere will give students a sense of security, and their subjective initiative will be brought into full play. Therefore, English teachers should strive to create a suitable atmosphere for students to learn and relax according to their psychological age characteristics, so that students can show their talents as much as possible.

\section{Making Efforts to Improve the Comprehensive Quality and Teaching Ability of English Teachers}

Many people evaluate the quality of a university, in addition to the necessary teaching equipment, the most important is the first class teacher team. Therefore, teachers are important driving force to promote the development of university education. In classroom teaching, teachers are dominant and the key to successful teaching activities. Teachers' ability level will directly influence classroom teaching. Therefore, the author believes that in order to improve the efficiency of classroom teaching, besides the students' subjective initiative, they should also improve the quality of teachers and teaching ability.

The deepening of educational reform and the social demand for high-quality English talents are becoming more and more stringent for College English teachers. Under this background, College English teachers must constantly improve their professional level to meet the needs of social development and talents, so as to cultivate more excellent talents. The teaching level of an excellent college English teacher is mainly embodied in its two aspects of foreign language theory and foreign language application skills. In terms of English theory, teachers should study deeply, so we should know how to teach and really link theory with practice. In terms of English skills, teachers can continue to summarize and research teaching skills according to their learning and teaching processes, and innovate teaching ideas, so as to meet the psychological needs of modern students and improve the efficiency of classroom teaching.

\section{Change the Teaching Method and Strengthen the Innovation}

Excellent college English teachers will put movies in the author's mind memories after the end of each class, to find their own shortcomings in the teaching process to be improved, or the analysis of students' possible questions and difficulties, in order to solve the problem of students in a class, the internalization of knowledge to help students better. Through continuous reflection, teachers can form their own teaching methods, and then combine the needs of the students to innovate. The author has summed up two methods from the practical teaching experience.

Restructured Textbook Method. In traditional teaching, teachers are taught in one page according to teaching materials. This teaching method lacks systematicness and integrity, so it is difficult for students to grasp textbooks as a whole. Especially the English discipline is very flexible, grammar, vocabulary, sentence structure and so on. If following the traditional way of teaching, it is very difficult to achieve the desired teaching effect. Therefore, teachers should change this teaching method, for example, the way to reorganize the teaching materials is based on teaching materials but not entirely dependent on the teaching materials. However, the reorganization of teaching materials requires English teachers to have strong professional ability, to divide teaching materials from a holistic perspective, to put together relevant knowledge points, and to cultivate students' overall awareness.

Knowledge Network Teaching Method. In College English classroom teaching, teachers can weave key and difficult knowledge into a systematic knowledge network to facilitate students' memory and learning. In the course of teaching, the teacher can explain to the students on the side of the concise outline, or can write the Related words, and make up a network of knowledge. According to learning needs, teachers can expand and compress knowledge network, and make abstract knowledge more vivid and simple, so as to improve classroom teaching efficiency.

In addition, the author believes that in addition to the above methods, teachers should impart their learning methods to students. It is called "teach the fish to fish better than getting the fish", and 
to cultivate the students' good habit of independent thinking and self-study.

\section{Conclusion}

To sum up, it is a long-term task to improve the efficiency of College English class. It needs patience and perseverance, and it can not be achieved overnight. As an English teacher, we should not only have professional teaching ability and knowledge structure, but also be able to face up to its status and role in teaching, actively innovate teaching ideas, and give full play to students' subjective initiative in classroom, so as to improve the efficiency of English classroom teaching.

\section{Reference}

[1] Yanjun Chang, Hui Liu. How to improve the effectiveness of College English Classroom Teaching[J].Campus English,2015.

[2] Binfang Li. How to improve the timeliness of English Classroom Teaching[J].Net friend world,2014.

[3] Zhaoying Li. How to improve the quality of College English Classroom Teaching[J].Goods and Quality,2014. 